\title{
The Role of Parepare Port in Trading and Shipping of Rice Commodities in South Sulawesi, 1930-1942
}

\author{
Syafaat Rahman Musyaqqat and Didik Pradjoko \\ Department of History, Faculty of Humanities, Universitas Indonesia, \\ Depok, West Java, Indonesia
}

DOI: https://doi.org/10.14710/jmsni.v4i2.8211

\begin{abstract}
The economic historiography in trading and shipping activity during the 20th century often linked up to the role of Makassar as the main port in Sulawesi supported the exchange of beneficial commodities, such as copra which was -deemed as the "green gold" of the archipelago. In terms of becoming the most prominent entrepot for international trading and shipping, there were also several ports in South Sulawesi that played a vital role in establishing a connection to the outside world with much more variety of commodities. It could find other commodities, such as rice, which was transported all across the

Received:

June 16, 2020

Revised:

December 26, 2020

Accepted:

December 27, 2020

${ }^{*}$ Corresponding Author:

didik.pradjoko14@gmail.com archipelago. Thus, this article argues that the Port of Parepare had a significant role in the trading and shipping of rice commodities in South Sulawesi, during the age of colonial administration (1930-1942). Through the historical method, the findings show that the Port of Parepare, throughout the 1930s, the Port of Parepare was not just a collecting port for Makassar, but also became the supplier of rice from the coastal area to the hinterland. Such synergistic collaboration, between the economic potential of the hinterland, agricultural intensification program, and colonial government regulation, encouraged the Port of Parepare to become the most imminent rice exporter in South Sulawesi during the 1930s. Moreover, within the same period, Parepare was also establishing interisland networks.
\end{abstract}

Keywords: Rice Commodity; Port of Parepare; Economic Potential; Colonial Regulation.

\section{Introduction}

“Belum makan kalau belum makan nasi" [you are not yet eating, if you haven't eaten any rice] was one of the most popular sayings in between Indonesians. Their fondness toward rice reflected the eating tradition held by most of them, making rice as the staplest component in the ingredients of many meals, which we could find in Indonesians' breakfast, lunch, and dinner, whether it acted as the appetizer, main course, or dessert. It consumed in a daily basis by everyone, putting aside all differences and classes available among the society.

Aside of being the source of food, rice also have sacred or spiritual meanings, immortalized within numerous folklores and legends that spread all across the archipelago. Each region has its own oral tradition in preserving the stories of rice. In Minahasa, as an example, they believed that their ancestor "stole" the rice from God, in order to add variation toward their staples, such as fruits or nuts (Henley 2004). The implication of such belief was affected toing the development of traditions, belief systems, and laws of many ethnic groups in Indonesia, making it evident that rice and its modifications were as old as the first civilization ever recognized in the region (Kroef 1952).

Boomgard (2003) explains that the consumption of corns and tubers as staples had increased since 1815 until days before the World War II took place. However, rice was also playing significant and dominant role, especially in Java in between 1500 and 1800. In the southern part of Sulawesi, rice was both for consumed and exported. According to Tome Pires, from 1512 to 1515, he found that the people in Makassar had already had networks of commerce toward Malacca, Java, Siam, and 
many other city ports around Pahang and Siam. They transported white rice, gold, bretangi (red cotton), and textiles from Bengal (Cortesao 2015). Other than that, Manuel Pinto, a Portuguese who temporarily settled at South Sulawesi between 1545 and 1548, was also noticed that rice had been exported as the main commodity around Malacca (Pelras 2006). In the next period, the ancient manuscript, Lontarak Bilang, was also holding the record about the existence of rice trading. The people who lived among the vicinity of Karebosi started planting rice in 24 Desember 1632 (Basang and Wahid 1986). Thus, rice planting and consumption was nothing new to Indonesians, especially the people in South Sulawesi. In a broader context, Reid (1992) described that rice, fish, and palm were three examples of the staple foods consumed and prepared by Southeast Asian peoples which came before the arrival of westerners.

During the age of VOC establishment, rice was used as the currency, in order to obtain spices from Maluku Islands. However, the popularity of rice changed substansively after the establishment of East Indies Colonial Administration. The colonial government decided to not only export rice, but also import some quantities to meet market expectation. They exported tons of rice, about 3,8 metric ton per annum, to their home country, the Netherlands, along 1827-1829. Meanwhile, countries at the peninsula area (Thailand, Indocina and Burma) were subsequent importers of rice to the colonial establishment down to the south. For the first time in the record, in 1847, the Dutch East Indies imported rice from Saigon. Later on, Dutch East Indies became the leading rice importer in the region with the support of numbers of newly established industries in which related to the increasing number of laborers that pushed the demand of rice production upward. Aside of that, the increasing population of the thriving colonial settlement took effect on the growing insecurities toward the possibility of production shortage, as the usual supply could hardly met the advancing demand (Moeljono 1971; Creutzberg 1987). In the other hand, the cultivation system relied heavily on the weather condition, while each region has their own situation, thus making the price of rice as a commodity of trade fluctuated. At this point, we could also acknowledge the availability of interisland trades that helped controlling the market price.

Java became the center of rice production. Meanwhile rice commodity was developed in Outside Java such as Eastern Sumatera, Bali, Lombok, and South Sulawesi. The production was then distributed to several local importers, such as Southwestern Sumatera, Bangka, Belitung, West Kalimantan, East Kalimantan, Manado, and Maluku. Aside of the political situation at that time, the establishment of Stichting Van Het Voedingsmidelenfonds (The Foundation for Food Funds) on April 1939 could be considered as the movement generated by the colonial government to put rice not only become the most important commodity, but also a beneficial matter for the continuity of the colonial grasp.

This study not only analyzes on the development of rice production or the economic growth caused by the mass cultivation, but also specifically analyzes the Port of Parepare's role in establishing a network of South Sulawesi rice trading, during the last decade of the colonial era (1930-1942). Rice could be seen as one of many commodities being exchanged among the Dutch East Indies, but also the prime mover, as well as the binding factor of local or interislands networks.

During the colonial period, there were only small numbers of ports in the whole region of South Sulawesi to cover shipping and trading. Some of them were located on the west and east coast, while some were on the south coast which is consisted of Port of Makassar, along with Port of Pallima, Bajoe, Palopo, Malili, Bantaeng, Takalar, Jeneponto, Pangkajene, Parepare, Majene, and Pambauwang. These ports have been fully operational long before the full colonial occupation of the region, which was characterized by the Dutch colonial's pacification at the earliest time ofthe early of the $20^{\text {th }}$ century. Among these ports mentioned above, the Port of Parepare was recorded for its prominent role in numerous historical sources. After the Great Depression in 1930s, it was explained further that Parepare held an important position in rice trading.

Several prominent historians have conducted research in the rice trade throughout history, such as Mansvelt (1978), Creutzberg (1987), van der Eng (1996), Prince (2000), Henley (2004) and Maat (2015). All studied the rice trade in the Dutch East Indies in general, but Maat specifically highlighted the rice trade around Sumatra. Booth $(2012,1156)$ reveals that at the end of the 19th century in several places in Sulawesi, tubers were the consumption of most people and rice was only used by the upper class. However, in his study entitled Trade and Economic Development in the Outer Islands 
1900-1942, Touwen (2001, 251-52) has emphasized that South Sulawesi had an attractive position in the maritime rice trade during the first half of the twentieth century. This opinion seems acceptable in several ways. From internal factors, South Sulawesi is a suitable area for agricultural areas, in addition to the existence of the Makassar port as a transit port for the Great East. Meanwhile, external factors from the position of South Sulawesi seem to be correlated with the study results of Booth (2019). By reviewing the living standards of Southeast Asian peoples throughout the twentieth century, she argues that there was a tendency for colonial governments in Southeast Asia to adopt more activist policies in order to promote economic development in each colony. In the Dutch East Indies, this policy was known as ethical politics which had been implemented since 1901. According to Booth, although the land settlement program had only a small impact on the poverty problem in Java, it had stimulated the movement of the population from landless Javanese families to Sumatra and Sulawesi (Booth 2019, 54). The displacement has of course opened wider opportunities, in this case labor, especially to intensify the cultivation of rice and other export commodities in areas outside Java in order to balance the internal demands of the international market.

In the context of trading in South Sulawesi, Heersink (1994) had analyzed copra trading in Selayar Islands, South Sulawesi and its effect toward locals, during the colonial era. Copra, according to Heersink, was acknowledged by many, at that time, as green gold, a commodity that was too hot for handle, even by the European traders, for there had been some kind of intervention given by Chinese traders. Similar to Heersink, Asba (2003) was also studying the production and distribution of copra around the Makassar as the eastern entrepot. Both Heersink and Asba didn't give much insight on the rice trading in the region. Recent study could be found in Nur, Purwanto and Suryo (2016), about trading and economic expansion in South Sulawesi during 1900s to 1930s. However, analyzes provided about rice trading was still focused on Makassar as the entrepot, as well as the largest port in South Sulawesi. Thus, this research provided a focused study on prior studies which might be missed beforehand.

Port become a part of studies in the study of maritime history. It holds a significant role in trading and shipping activities that we could not just study both activities as an active displacement of goods and people, but also an activity of distribution, started at the tip of the ports, which then Braudel (1972) elaborated as: there would be no routes if there were no stopping-places. Ports act as the stopping point, either permanently or temporarily, for all ships and boats sailing across the sea. Ports are also the key for mere cities to come into existence; to become more to a cosmopolitan entity that they were not before (Murphey 1989). In this article, Parepare didn't belong to the category of harbor, but more into a port that encouraged economic activities and development (Sulistyono 2004). Aside of having social and economic function, the port may at times also have a military function, as we could see it on the case of the Port of Cilacap (Zuhdi 1994). Then, perhaps, it is not that bold to mention ports as the real market place with multiple functions (Pradjoko and Utomo 2013).

Typologically, according to Heng (1990), ports are divided into three kinds, i.e.: entrepot, collecting centre and feeder point. Entrepot acts as the center of economic activity, especially on largescale tradings and exchanges, with a more complexity in the variation of the commodities and in the volume of transactions, while feeder point is the in-between spot between entrepot and collecting centre, as well as the source of commodities. Meanwhile, there are at least four characteristic of collecting centre, which are: (1) geographically strategic and naturally "friendly" for docking and loading activity; (2) located at an area that relatively adjacent to source of food or local market for sojourners in taking their stopovers; (3) a good place with hinterlands that could support the port area further; and (4) a profound emporium of the region (Zuhdi 2010). Therefore, this article analyzes the port of Parepare according to its role as the collecting center in the broad context of trading and shipping activities in the region of South Sulawesi.

\section{Method}

The historical method has been used to examine the role of Parepare Port in trading and shipping of rice commodity. It consists of four steps to be accomplished such as; heuristic, critics, interpretation, and historiography. During the heuristic, primary sources have been gathered, such as the colonial records as well as newspapers and magazines, from the National Archives of Indonesia and National 
Library, as well as in the digital platforms such as Delpher.nl. Meanwhile, the secondary sources also have been used from other documentation platforms. These sources were then criticized to check on their validity, before historians could interpret it further, and then assemble it into a subjective reconstruction of the past.

This study is about the history of maritime economics, by taking the Port of Parepare as the spatial limitation of this article, as well as 1930-1942 as the temporal limitation. 1930 was selected as the point when where the research started because there had been a significant increase in the trading activity, even during the Great Depression, while 1942 was picked out due to the fact that the colonial administration had been taken over by Japan's occupation at that year.

\section{The Port of Parepare at Glance}

The Port of Parepare was one of many ports located within the proximity of South Sulawesi, especially along the west coast of the area. The port is located 76 miles to the north of the Port of Makassar, at the Bay of Parepare. It was actually all covered by the Cape of Lero, which protected the bay area from the open sea of Makassar Strait, making it as a safe docking, loading, and sojourning port throughout the year. According to Lapian (2008), one of the endorsing factors was such ecological opportunity of the bay. Thus, the development of Parepare was pretty much related to its geographical condition, which supported Parepare to become a natural collecting center.

If we would like to analyze the condition through the political point of view, since the $16^{\text {th }}$ century, the Bay of Suppa (now the Bay of Parepare) had been the heart of Parepare. But, in the early $19^{\text {th }}$ century, Parepare was handed over by British colonial to the local ruler of Sidenreng. In the ratified version of the Treaty of Bongaya in 1824, Parepare was firmly claimed as a part of colonial administration, but somehow being borrowed by the Kingdom of Sidenreng. This was the situation happened in Parepare, before the political pacification movements were carried out by the colonial establishment toward South Sulawesi from 1905 to 1906 . After the military oppression in the early $20^{\text {th }}$ century, conducted by the Dutch colonial to expand their dominance over the eastern part of the archipelago, the whole South Sulawesi was marked as under the administration of the Dutch colonial, including Parepare. South and Southeast Sulawesi were then administratively divided into seven afdelings (domains) in 1911, all of which were Makassar, Bonthain, Bone, Parepare, Luwu, Mandar and Buton, as well as the East Coast of Sulawesi. Within such context, Parepare was then become an individual afdeling in South Sulawesi (Staatsblad van Nederlandsch Indie 1910, No. 573).

In the second half of the 19th century, Dutch East Indies' waters were crowded by the arrivals and departures of many boats and ships, conducting economic activities and many other exchanges and transactions. On one hand, the increasing number of arrivals and departures at various Nusantaran ports was caused by British colonial liberal proposal on opening the Suez Canal in 1869, in order to maximize the revenue on export-import activities. On the other hand, these heavy passingby activities were somehow could not affect smaller ports with their minor routes, since these ports and routes hadn't yet recognized by the colonial government as their regular trading and shipping circles. These ports and routes were located mostly on the Outer Java area, especially the eastern region. Therefore, the colonial government decided to expand the reach of NISM's shipping route, in cooperation with H.O Robinson (since 1865). At that time, Parepare was still under the control of Sidenreng, but included anyway into one of the subsidized trading and shipping routes in 1876 . Other than Parepare, some smaller ports were also included to the routes, such as those along the coast of Kalimantan, Palu, Maluku, and Nusa Tenggara (Sulistyono 2003).

It was pretty interesting to realize that Parepare had actually caught the attention of government's shipping company, or how it was recognized further in the route, along with many other smaller ports mentioned above. However, the question is why or how? Brink (1884) took us back in time to inspect the whole activities carried out in the second half of $19^{\text {th }}$ century South Sulawesi. According to him, Parepare experienced a significant development when Bugis traders withdrew to the port after the closure of the Bone port on the east coast of South Sulawesi in 1860. According to him, Parepare experienced significant development when Bugis traders withdrew to the port after the closure of the Bone port on the east coast of South Sulawesi in 1860. He also said that Parepare was a more profitable and strategic port for direct trade relations with Singapore, which since 
1819 was developed by the British as a free port. This is certainly not an exaggeration considering the position of Parepare as a port that was not yet under the direct control of the Dutch colonial government. That advantageous position was also reflected in the revenue of the Kingdom of Sidenreng at the Port of Parepare in 1873 which reached 20,000 gulden (Pelras 2006).

Moreover, the trading and shipping route that involved Parepare, Palu, and the East Coast of Kalimantan was perhaps the example of the most splendor route of commerce at that time. The Strait of Makassar was also playing significant role, by drawing the attention of the colonial government to establish further maritime connection to the east. After the contract between NISM and O.H. Robinson gone expired, a new company, Koninklijk Paketvaart Maatschappij(KPM) had the matters related to trading and shipping in the Dutch East Indies took over, since 1888, and still prioritizing South Sulawesi as one of the main routes to the east. KPM once had an expedition to the eastern part of the archipelago, under the neat plan of L.D.P. ten Noort in 1890, to study the situation and potential of the Dutch East Indies' maritime expansion. During the expedition, Ten Noort saw the obvious potential in the trading and shipping line between Makassar and Singapure (Sulistyono 2004).

However, the company had just started its pilot operation in 1891, carrying out the regular activities once pioneered by NISM, thus making Parepare belonged to the same situation as it was before 1890. KPM served at least 19 subsidized shipping routes under the control of the Dutch colonial government. Two routes, Route No. 9 and Route No. 14, was the route that included Parepare as stopover. Both routes were active in January $17^{\text {th }}, 1891$, making journey from and for Surabaya fortnight (Poelinggomang 2016).

As a collecting center type of port, the livelihood of the Port of Parepare could not be separated from the robust existence of its hinterland, rich and productive in both agricultural and economic sectors. The hinterland area produced rice on its lowlands and coffee on highlands. However, we do need to emphasize that the hinterland of Parepare was referred to the rural areas near or surrounding the port, including the seaport, coastal area, and even far to the highlands, for each of them had significant economic relationship (Supriyono 2001).

As we could understand from the paragraph above, we acknowledged that Parepare was geographically divided into two parts of area, the highlands and the lowlands. The lowlands, including Sidenreng-Rappang, Pinrang, Barru, Parepare, and even Mandar and Selayar, would be our main focus, as these areas produced rice as trading commodities for Parepare. As in the case of Mandar and Selayar, both areas were administratively belonged to the Afdeling Parepare. Sidenreng was noticed as the main supplier of rice to the Port of Parepare (Pemberita Makassar 17 Mei 1915). These areas were known for their fertile nature because of the type and the structure of the soil, which were the end result of sedimentation, as well as alluvial soil. Both types were believed to be the key of agricultural success in the areas, especially to meet the ever-increasing demand of foodstuffs. Such condition was also supported by Lake Sidenreng, which provided a rather convenient irrigation system (Sadi 2014). According to the report made by Manuel Pinto, a Portuguese who happened to visit the areas in 1548, such prosperous condition had lasted for centuries in Parepare. As he told in Pelras (1983):

"I think this area was the best land I had ever seen in the entire world, because I could see the rice being cultivated on its land, while cattle, fish, and fruits were very abundant. It was located near the lake, where boats, large and small, were sailing across relentlessly. We could also see prosperous town on the surrounding area."

Other than rice, other commodities cultivated for the sake of commerce by the people inhabiting the Afdeling of Parepare were maize, nuts, lentils, and copra. However, these commodities didn't provide much returns, especially copra, which was still far below the production of other afdeling in South Sulawesi. Entering the early 1920s, copra started to be recognized as a profitable commodity, as the government decided to open 3.055 hectares of land to establish plantation in the afdeling (De Indische Mercuur 30 Januari 1920).

As for rice production, Parepare received ample supplies from Ajatappareng, Segeri (Onderafdeling Pangkadjene), and Takkalasi (Onderafdeling Soppeng). According to the writings of J.A van Beukering, these areas transported rice to Parepare through land route (by car) in 1934 
(Hamid 2019). Other than that, the areas belonged to Afdeling Mandar were also taking parts as suppliers of various commodities to Parepare, such as dried fish and fruits (Luhukay and Tuwanakotta 2006), while Selayar supplied Selayar's citrus to be exported (Noteboom 1938).

Other commodities were supplied by the highlands, such as Enrekang, Makale, and Rantepao, with Makale and Rantepao were administratively belonged to Afdeling Luwu. Coffee beans were their signature commodity, cultivated on the topsoil, 800-1000 metres above the sea level, with lush trees on its surroundings, these areas were very suitable for coffee plantation. In the end of the $19^{\text {th }}$ century, coffee beans produced by Toraja Highland were becoming the subject of dispute between Sidenreng and Luwu. Sidenreng wanted to exported the production to Parepare, while Luwu insisted it to be transported through Palopo. Sidenreng, perhaps, clearly won the contention, because during the political expansion of the Dutch colonial in 1906, Sidenreng managed to alter all transportation of coffee beans to Parepare (Bigalke 2016). In Alla, a part of Onderafdeeling Enrekang, some coffee beans plantations were also found, belonged to the locals. About 1.000 (around 100 catties, or 61,76 kilograms) of coffee beans per annum were produced. In 1925, these coffee beans were sold in the open market for $f 40-60$ per pikul in Kalosi (Alla Market) - Bungin and Kalosi - Parepare. But, these produces from Enrekang were generally transported to Parepare, then exported further to Makassar (Bundel Wyzingen En Aanvullingen van de Militaire Memorie van Enrekang van 19181922; Aucella 1925).

Based on the explanation regarding the relationship between the port and its hinterland above, we could understand how the agricultural component of Parepare imposed robust and beneficial effects toward the recognition of the port by the colonial government. The Port of Parepare clearly gave the insight of potential to the government; of how manageable it could become in the future. However, the idea wasn't pretty much followed by the government, since there hadn't been much change applied toward the infrastructures of the port as collecting center, even after two decades of the $20^{\text {th }}$ century.

A docking station was established in 1908, but only get its lighthouse by the year of 1928 , established near the Cape of Lero (Koloniaal Verslag 1908; 1928). Meanwhile, according to a newspaper in 1915, there were only two storages available near the market (Pemberita Makassar 17 May 1915). The land route was another thing. The main road that connected Parepare and Makassar was still in an unlikely condition to carry out regular transport by car. There were also no bridges for river crossing, as well as the lack of bordering signs between areas, such as in the border between Pangkajene (south of Parepare) and Makassar. The only available river transport was just few rafts (Pemberita Makassar 11 June 1915).

\section{Role of the Port of Parepare}

After the liberation movement, the usage of steamships and motorboats in the Dutch East Indies were increasing substantially, intensify the interislands networks alongside the international shipping lines. The numbers of steamships and motorboats were increasing from 25 units in total in 1870, to 378 units in total in 1939 (Sulistyono 2004).

The increasing number of rice trading in all across the Dutch East Indies could be seen throughout the statistical record in the decade on 1930s. Tons of rice were being exported, as well as imported, to meet the sky-rocketing demand of rice. In this decade, most ships and boats crossed the archipelago were carrying rice, both from and to Java as the center of all colonial economic activities (Dick 1988). Outer Java area was known for their prolonged dependency toward rice, but failed to produce enough to supply the demand, ended up importing rice from Java and many other producing areas. Touwen (2001) elaborated three factors that could explain the growing tendency of importing rice from areas outside Java: (1) the people of the area were putting too much concern on cash crop system; (2) the infertility of the soil; and (3) the need of laborers on many Europeans' plantations. However, these factors could not specifically explain the ever-increasing number of imported rices to South Sulawesi.

The role of the Port of Parepare in the rice trading in South Sulawesi begor the decade of 1930s could not be analyzed further, if we tried to make a comparation with the number of exported goods during the Great Depression of 1930. The main factor of the increasing number is the local condition 
of Parepare, which was still relying heavily on the traditional irrigation system. The rice exported through the port were recorded in according manner, such as 124 tons in 1915, 2.557 tons in 1916, 4.500 tons in 1921, and 7.800 tons in 1924 (De Indische Mercuur 30 January 1920; 10 July 1925). These recorded numbers were relatively menial, in comparison with the numbers recorded during the decade of 1930s, which even could reach more than 10.000 tons per annum. Other than that, there were other factors such as the lack of infrastructural development and competitive manners of other smaller ports, especially the Port of Pallima (Bone). Pallima was located in the east coast of South Sulawesi and got its supplies from its hinterland, connected by Cenrana River, which flows ended at the Bay of Bone (De Indische Courant 7 August 1937).

Such agricultural potential of South Sulawesi started to be developed further in 1919, especially on the Afdeling Parepare. A mantri, or an agricultural councellor, was assigned in 1921 to carry out the duty at the afdeling. Even a mantri was also assigned at Onderafdeling Enrekang, a less dominant part of Afdeeling Parepare in rice producing. These agricultural councellors helped and evaluated the locals' effort in intensifying rice cultivation, in order to gain maximum result (Bundel Wyzingen En Aanvullingen van de Militaire Memorie van Enrekang van 1918-1922; Nur 2003). The new irrigation system was also built throughout the 1930s, among others were the system at Saddang, Bila, Bulutimurung, Alakoeang, Kitoe-Kiroe and Batubessi. All established at Afdeeling Parepare (Allart 1933).

Eventually, the number of rice production was increasing. This helped boost the rice transported to Parepare. Until the end of 1930s, rice production in the whole South Sulawesi came from the production line at Sidenreng, Rappang, and Sawitto. The common type of rice found in the vicinity was Banda rice (Handelsvereeniging-Exporteursvereeniging Makassar Jaarverslag over 1938). It can be presented in the Figure 1.

\section{Figure 1 The Production of Rice in South Sulawesi, 1936-1940 (in tons)}

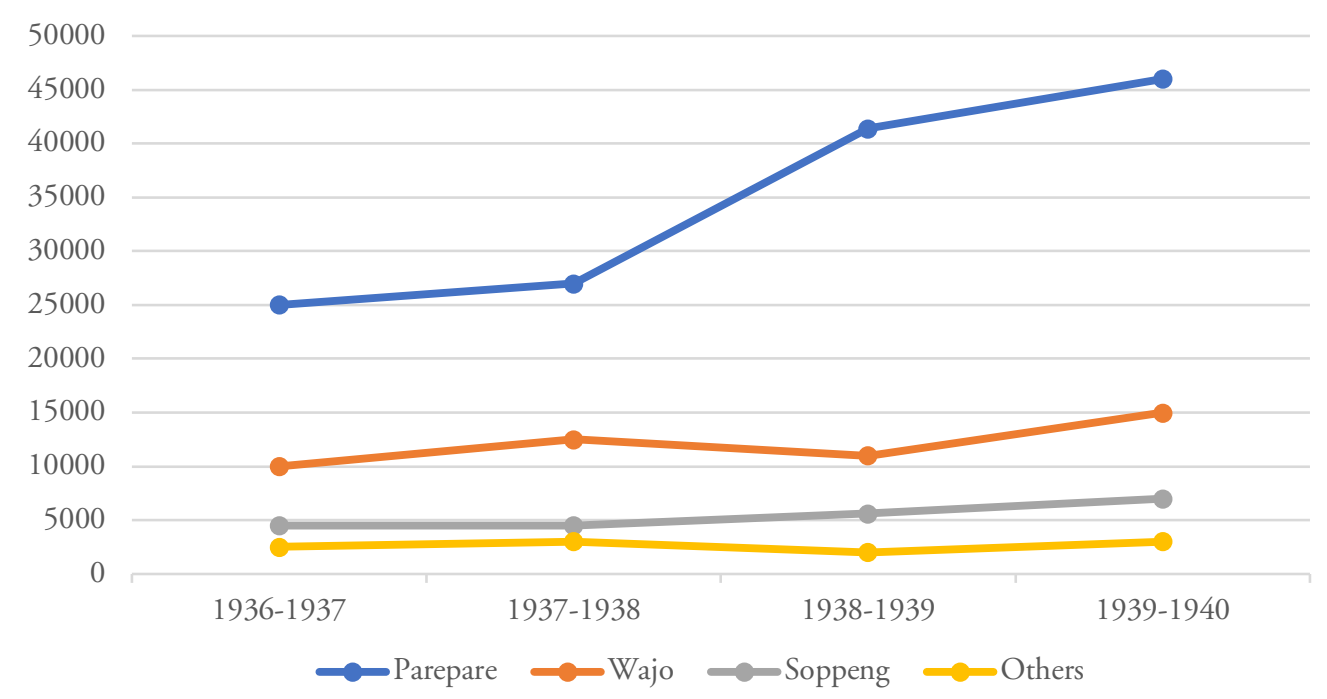

Source: Nur, Purwanto, and Suryo 2016.

In accordance with the establishment of rice milling factories in South Sulawesi, we could conclude that rice production in the region had already entered another level of economic achievement. The same pattern was found in other regions all across the Dutch East Indies, when the colonial government introduced the agricultural intensification program in the 1920s. There were at least 16 milling factories in South Sulawesi in 1930. But, in 1940, the number was increasing to 40 factories, with most of them located near Parepare (Harvey 1989).

According to sources gathered, a modern milling factory was established around the area of the Port of Parepare in June $9^{\text {th }}$, 1939. It was named as Laoemma-Hamid Milling Factory, operated with the capacity of grinding 20 pikul of rice per hour. With such advanced technology of that time, the factory was able to produce rice with higher qualities, in comparison to those produced outside Parepare, throughout the entire South Sulawesi. This was, in fact, an interesting finding because the 
establishment of Laoemma-Hamid Milling Factory was actually initiated by the Buginese, instead of the already-succeed three Chinese traders with their own economic enterprises (Soerabaijasch Handelsblad 17 Juny 1939). Then, how could the Buginese manage to have such predisposition? They even manage to forecast a better opportunity than their Chinese counterparts. This could lead to another research about rice trading in South Sulawesi, but the most important part was that the establishment of the factory had brought positive impact toward the production at the end of the 1930s.

The rice produced in South Sulawesi was transported to many rice-dependent areas, such as Kalimantan, Manado, Maluku, Timor, and even Java itself (Hamid 2019). In the early period of the $20^{\text {th }}$ century, rice from South Sulawesi was also exported internationally to Australia and New Guinea (Nur, Purwanto, and Suryo 2016). It was transported from three major ports in Sulawesi, which were Makassar, Parepare, and Pallima. According to Hamid, Parepare supplied only Mandar and the eastern part of Kalimantan, but this could still be studied further to find out whether Parepare was also transporting rice to other areas.

In fact, the shipping lines available during that time took many traders to transport rice from Parepare to Donggala and Manado. In 1932, the number was recorded. Parepare, as well as Makassar, transported more than 4.500 tons of rice to Manado. In the following year, the number was increased to 6,750 tons (De Indischee Mercuur 17 January 1934). Meanwhile, way before the $20^{\text {th }}$ century, Donggala had imported rice from Parepare and Surabaya in 1897 for about 1.045.432 kilograms (Nadjamuddin et al. 2016).

The role of the Port of Parepare was strategically related to South Sulawesi's rice export throughout the 1930s, and was recorded in a very according manner in many archival sources. In the Memorie Van Overgave (MVO/Document of the Withdrawed, Retiring, or Decommissioned Government's Officials) of Parepare Assistant Resident, J.A. Allart, we could find the information regarding the number of commodities exported from 1928 to 1932, from the port. 17.290 out of 23.000 tons of loads were registered as rice. Therefore, during such short period of time, $75 \%$ of the commodities being traded and shipped was rice (Allart 1933). Another source implied that the number of rice exported from South Sulawesi had reached more than 47.000 tons in 1934, which then transported from Parepare (37.000 tons), Makassar (10.000 tons), and Pallima (around 4.170 tons) (Jaarverslag van de Handelsvereeniging Te Makassar over 1934).

Economisch Weekblad recorded that the transportations of rice from South Sulawesi in between 1928 and 1936 were carried out from three different ports (Makassar, Parepare, and Pallima), with most of the load taken to Kalimantan, and only few were sent to Timor. This record set the number transported to Manado aside, with the estimation of more than 20.000 tons (Hamid 2019). Hence, according to these sources, we could understand how the Port of Parepare became one of the busiest ports in South Sulawesi, all due to the increasing production and distribution of rice to various areas in the archipelago.

Regarding the copra trading, South Sulawesi was long known as copra producing region (Sato 2006; Heersink 1999; Asba 2003). However, the fact through our findings about Parepare, during the 1930s, we could not reach the conclusion that copra held the position as main commodity of trading and shipping activities in the decade, but only a part of a larger domain. In fact, also according to our findings about Parepare, every ports transported various commodities, encouraging the products transported to be as variative as possible. The important thing to be highlighted here was the intra-island and interisland networks established by the ports.

Another factor, perhaps, could be the derivative effect of Rijstinvoer-ordonantie 1933. This regulation (ordinance) issued by the colonial government, was meant to control the exceeding number of imports by imposing certain quotas toward rice imports from outside of the colony. Aside of that, the ordinance was introduced to stabilized the market, for the price of rice in the open market had been gradually diminished since 1930, especially after the Great Depression (Prince 2000; Moeljono 1971). Government's action on controlling the price of rice succeeded, as we could see how the price in Parepare was stabilizing, at around f 3-3,5 per pikul (Allart 1933).

The people of Parepare utilized steamship, motorboat, as well as locals' sailing vessels to transport rice from one spot to another. However, similar to the research conducted by Susilowati (2004) about Banjarmasin, these small boats still played significant roles, even though they could only 
transport a rather small quantity of goods. During the Great Depression, the locals' sailing vessels were no longer mere feeder vessels, but became the backbone of the transportation far to the hinterland in a relatively cheap and practical manner. The utilization of shipping was also due to the monsoon wind flowing around the Strait of Makassar, which actually beneficial for such vessels, making the interconnection between Kalimantan and Sulawesi possible. Further relations were developed between communities in the west coast of Sulawesi, such as Makassar, Parepare, Majene, Donggala, Kaili, and Suppa, and the center of commerce along the east coast of Kalimantan, such as Banjarmasin, Kutai, Samarinda, and Bulungan (Poelinggomang 2016).

Moreover, in the context of shipping activities in Parepare, Buginese and Mandar sailors were also holding prominent role as the playmaker within the trade winds. Traditional boats, such as Padewakang, Palari, Lete, and Lambo, were types of boat known for their strength and agility (Hamid 2019). In 1935, there were at least 60 sailing vessels operated on daily basis at Parepare (Statistiek van de Scheepvaart in Nederlandsch-Indie over Het Jaar 1935).

The role of the port was increasing subsequently after rice trading grown to be a popular kind of trade in South Sulawesi, as the number of boat arrivals and departures were dynamically shifting from time to time. Before entering the third decade of the $20^{\text {th }}$ century, we could see that, in the 1920s, the numbers had already increased. 151 vessels in 1922 with $292.612 \mathrm{~m}^{3}$ on deck, 212 vessels in 1925 with $517.476 \mathrm{~m}^{3}$ on deck, and 195 vessels in 1929 with $575.391 \mathrm{~m}^{3}$ on deck. It was quite fluctuative (Statistiek van de Scheepvaart in Nederlandsch-Indie over Het Jaar 1931).

In a study titled Perdagangan Antarpulau, Pengintegrasian Ekonomi, dan Timbulnya Suatu Perekonomian Nasional, Dick (1988) concluded that in many decades on the 1930s, there was a rather significant rise in the loading capacity, as well as the pricing in various markets. According to Dick's analyses, the increase of rice production was followed by the diminishing import activities, until 1940, making the whole Dutch East Indies almost self-sufficient (Dick 1988). Thus, we could see the data regarding the annual boat arrivals, along with the loading capacity, at Parepare on the Table 1.

Table 1. The Arrival of Boats and Ships at Port of Parepare, during 1930-1935 (along with the capacity)

\begin{tabular}{ccccc}
\hline \multirow{2}{*}{ Year } & \multicolumn{2}{c}{ Boat(s) } & \multicolumn{2}{c}{ Ship(s) } \\
\hline 1930 & 1.722 & 37.285 & Number & Nett weight $\left(\mathrm{m}^{3}\right)$ \\
1931 & 1.649 & 40.903 & 213 & 599.417 \\
1932 & 1.461 & 38.200 & 165 & 481.877 \\
1933 & 1.406 & 40.692 & 172 & 345.004 \\
1934 & 1.698 & 48.310 & 192 & 433.443 \\
1935 & 1.610 & 47.846 & 192 & 628.965 \\
1936 & 1.264 & 42.209 & 184 & 516.587 \\
1937 & 1.578 & 53.672 & 172 & 492.020 \\
1938 & 2.088 & 67.483 & 162 & 509.620 \\
1939 & 2.196 & 68.073 & 154 & 431.961 \\
\hline
\end{tabular}

Source: Statistiek van de Scheepvaart Nederlandsch-Indie over het Jaar 1930; 1939

According to the statistical data provided in Table 1, we could see how the Great Depression affected the activity at the port, during 1930-1932, both identified by the declining number of boat arrivals and the goods they were transporting. This was caused by the decreasing price of rice at the open market. However, the number slightly altered in the next following years. Boat arrivals were growing higher and higher from 1933 to 1939, and slowing down for a brief moment in 1935 and 
1936. Hence, within the exact same time, the number was still growing, showing dynamics of the trading and shipping activities, until it was starting to subside within the last four years.

In addition to the statistical data, we also had to acknowledge the role of KPM in supporting the activities through its fleets and shipping lines. KPM opened numbers of new shipping routes, so that Parepare benefited the extra four lines, Route No. 13, Route No. 17b, Route No. 19, and Route No. 20 in 1936, after the contract between the company and the government got renewed. From Route No. 13, Parepare benefited from the shipping routes that crossed Makassar, Donggala, Balikpapan, Samarinda, Pasir, Pamukan, Kota Baru, and Banjarmasin (Dienstregeling Der Koninklijke Paketvaart Maatschappij Voor Het Jaar 1924; 1936). These extra lines were proven to be a significant incentive for Parepare's self-development, at least to the very last days of colonial administration in the East Indies.

\section{Conclusion}

Rice had also been the key to the Port of Parepare's advancement, encouraging the collecting center to come into existence, and then becoming one of the busiest ports in the Dutch East Indies, and of course South Sulawesi. Parepare had transformed itself to a thriving polity, even though it had been caught in static in the early of the $20^{\text {th }}$ century. The agricultural intensification program, initiated by the colonial government in South Sulawesi since the decade of 1920s, helped the port to cope with the challenge, and then rise to a prosperous condition. Afdeeling Parepare managed to take advantage over the concurrent circumstances to stimulate larger production of rice, and got recognized by the colonial government in 1930s. Such glorious moment for Parepare lasted until the end of the colonial administration grasp over its colony. By that time, Parepare had established a sustainable network across South Sulawesi, through both intra-island and interisland trading and shipping, as well as developed respectable infrastructures for the sake of rice production and distribution, such as better land routes for transportation and modern milling factories. Thus, it may be just fine to identify the Port of Parepare as one of the busiest ports in the entire Dutch East Indies, with further specialization in rice producing and distributing, that actually altered the way we understand the role of smaller ports.

\section{References}

Allart, J. 1933. Memorie van Overgave van de Afdeeling Parepare.

Asba, Abdul Rasyid. 2003. "Ekspansi dan Kontraksi Ekspor Kopra Makassar 1883-1958."PhD Dissertation, Universitas Indonesia.

Aucella, A. 1925. Oosthoek's Geilllustreerde Encyclopaedie, Tweede Druk, Deel I. Utrecht: A. Oosthoek.

Basang, Djirong, and Sugira Wahid. 1986. Lontarak Bilang Raja Gowa Dan Tallok (Naskah Makassar). Ujung Pandang: Departemen Pendidikan dan Kebudayaan.

Bigalke, Terance W. 2016. Sejarah Sosial Tana Toraja (M. Yuanda Zara, Trans.). Yogyakarta: Ombak.

Boomgaard, Peter. 2003. "In the Shadow of Rice: Roots and Tubers in Indonesian History, 15001950." Agricultural History 77 (4): 582-610.

Booth, Anne. 2012. "Measuring Living Standards in Different Colonial Systems: Some Evidence from South East Asia, 1900-1942." Modern Asian Studies 46 (5): 1145-81.

Booth, Anne. 2019. "Living Standards in Southeast Asia: Changes over the Long Twentieth Century, 1900-2015." Amsterdam: Amsterdam University Press.

Braudel, Fernand. 1972. The Mediterranean and the Mediterranean World in the Age of Philip II. 1 (Sian Reynolds, Penerjemah). New York: Harper \& Row.

Brink, P.B. Standen ten van. 1884. Zuid Celebes Bijdragen Tot De Krijgsgeschieen Militaire Geographie van de Zuidelijke Aandtong van Het Eiland Celebes. Utrecht: Kemink \& Zoon.

Bundel Wyzingen En Aanvullingen van de Militaire Memorie van Enrekang van 1918-1922.

Cortesao, Armando. 2015. Suma Oriental Karya Tome Pires: Perjalanan Dari Laut Merah Ke Cina \& Buku Francisco Rodrigues. Yogyakarta: Ombak. 
Creutzberg, Pieter. 1987. Sejarah Statistik Ekonomi Indonesia. Jakarta: Yayasan Obor Indonesia.

Dick, Howard. 1988. "Perdagangan Antar Pulau, Pengintegrasian Ekonomi dan Timbulnya Suatu Perekonomian Nasional." In Sejarah Ekonomi Indonesia, edited by Anne Booth, Willian Joseph O’Malley, and Anna. Weidemann, 399-434. Jakarta: LP3ES.

Dienstregeling Der Koninklijke Paketvaart Maatschappij Voor Het Jaar 1924; 1936.

Eng, Pierre van der. 1996. Agricultural Growth in Indonesia: Productivity Change and Policy Impact since 1880. New York, N.Y.: St. Martin's Press.

Hamid, A. R. 2019. "Jaringan Maritim Mandar: Studi Tentang Pelabuhan 'Kembar' Pambauwang Dan Majene Di Selat Makassar1900-1980." PhD Dissertation, Universitas Indonesia.

Handelsvereeniging-Exporteursvereeniging Makassar Jaarverslag over 1938.

Harvey, Barbara S. 1989. Pemberontakan Kahar Muzakkar : Dari Tradisi ke DI/TII. Jakarta: Pustaka Utama Grafiti.

Heersink, Christiaan. 1994. "Selayar and the Green Gold: The Development of the Coconut Trade on an Indonesian Island (1820-1950)." Journal of Southeast Asian Studies 25 (1): 47-69.

Heersink, C. 1999. Dependence on Green Gold: A Socio-Economic History of the Indonesian Coconut Island Selayar. Leiden: KITLV Press.

Heng, Leong Sau. 1990. "Collesting Centres, Feeder Points and Entrepots in the Malay Peninsula 1000 B.C - A.D. 1400." In The Southeast Asian Port and Polity: Rise and Demise, edited by J. Kathirithamby- Wells and John Villiers, 17-38. Singapore: Singapore University Press.

Henley, David. 2004. 'Rizification Revisited Re-Examining the Rise of Rice in Indonesia with Special Reference to Sulawesi'. In Histories of Foodcrop and Livestock Farming in Southeast Asia: Smallholders and Stockbreeders, edited by Peter Boomgaard and David Henley, 107-38. Leiden: KITLV Press.

De Indische Courant 7 August 1937.

De Indische Mercuur 10 July 1925; 30 January 1920; 17 January 1934.

Jaarverslag van de Handelsvereeniging Te Makassar over 1934.

Koloniaal Verslag 1908; 1928.

Kroef, J.M. van den. 1952. "Rice Legends of Indonesia." The Journal of American Folklore 65 (225): 49-55.

Lapian, Adrian B. 2008. Pelayaran dan Perniagaan Nusantara Abad Ke-16 Dan 17. Depok: Komunitas Bambu.

Luhukay, H, and E Tuwanakotta. 2006. Memori Asisten Residen W.J. Leyds Selama Bertugas Di Mandar. Makassar: Yayasan Kaitupa.

Maat, Harro. 2015. "Commodities and Anti-Commodities: Rice on Sumatra 1915-1925." In Rice : Global Networks and New Histories, edited by Francesca Bray, Peter A Coclanis, Edda L. FieldsBlack, and Dagmar Schafer, 335-54. New York: Cambridge University Press. https://doi.org/https://doi.org/10.1017/CBO9781107360266.

Mansvelt, W M F. 1978. Changing Economy in Indonesia: : A Selection of Statistical Source Material from the Early 19th Century up to 1940/Volume 4 Rice Prices. The Hague: Nijhoff.

Moeljono, Sidik. 1971. Seperempat Abad Bergulat dengan Butir-butir Beras. Djakarta: Bulog.

Murphey, Rhoads. 1989. "On the Evolution of the Port City." In Brides of The Sea: Port Cities of Asia from the 16th-20th Centuries, edited by Frank Broeze, 223-46. Kensington: New South Wales University Press.

Nadjamuddin, L, I. A Rore, I Ahmad, and Wilman Darsono. 2016. Satu Kota Empat Zaman: Donggala Pada Masa Tradisional Hingga Terbentuknya Kabupaten. Yogyakarta: Ombak.

Noteboom, C. 1938. "Economisch Onderzoek van de Inheemsche Samenleving in Zuid-West Celebes." Koloniale Studiën 1: 624-32.

Nur, Nahdia. 2003. "Perdagangan Beras di Makassar Awal Abad XX." Lembaran Sejarah 5 (1): 8394.

Nur, Nahdia, Bambang Purwanto, and Djoko Suryo. 2016. "Perdagangan dan Ekonomi di Sulawesi Selatan, Pada Tahun 1900-an sampai dengan 1930-an." Jurnal Ilmu Budaya 4 (1): 617-24.

Pelras, Christian. 1983. "Sulawesi Selatan Sebelum Datangnya Islam Berdasarkan Kesaksian Bangsa Asing." In Citra Masyarakat Indonesia, edited by Marcel Bonneff, 56-82. Jakarta: Sinar Harapan. 
Pelras, C. 2006. Manusia Bugis (A.R. Abu, Trans.). Jakarta: Nalar.

Pemberita Makassar 11 Juny 1915; 17 May 1915.

Poelinggomang, Edward L. 2016. Makassar Abad XIX: Studi Tentang Kebijakan Perdagangan Maritim. Jakarta: KPG.

Pradjoko, Didik, and Bambang Budi Utomo. 2013. Atlas Pelabuhan-Pelabuhan Bersejarah Di Nusantara. Jakarta: Direktorat Sejarah dan Nilai Budaya, Direktorat Jenderal Kebudayaan, Kementerian Pendidikan dan Kebudayaan.

Prince, G.H.A. 2000. "Kebijakan Ekonomi Di Indonesia, 1900-1942." In Sejarah Ekonomi Modern Indonesia: Berbagai Tantangan Baru, edited by J. T Lindblad, 226-56. Jakarta: LP3ES.

Reid, Anthony. 1992. Asia Tenggara dalam Kurun Niaga 1450-1680, Jilid 1: Tanah di Bawah Angin (Mochtar Pabottingi, Trans.). Jakarta: Yayasan Obor Indonesia.

Sadi, Haliadi. 2014. "Keresahan Sosial di Sulawesi Selatan: Kasus Sidrap di Tahun 1950-an." In Negara dan Masyarakat Sulawesi Selatan di Tahun 1950-an, edited by Dias Pradadimara, M.B.A Teng, and Herry Kusuma Tarupay, 49-80. Yogyakarta: PT Kanisius.

Sato, S. 2006. "Indonesia 1939-1942: Prelude to the Japanese Occupation." Journal of Southeast Asian Studies 37 (2): 225-48.

Soerabaijasch Handelsblad 17 Juny 1939.

Staatsblad van Nederlandsch Indie 1910, No. 573.

Statistiek van de Scheepvaart in Nederlandsch-Indie over Het Jaar 1930; 1931; 1935; 1939.

Sulistyono, Singgih Tri. 2003. "The Java Sea Network: Patterns in the Development an of Interregional Shipping and Trade in the Process of National Economic Integration in Indonesia, 1870s-1970s." Leiden: Universiteit Leiden.

Sulistiyono, Singgih T. 2004. Pengantar Sejarah Maritim Indonesia. Jakarta: Direktorat Jenderal Pendidikan Tinggi.

Supriyono, Agus. 2001. "Hubungan Antara Pelabuhan Dengan Daerah-Daerah Hinterland: Studi Kasus di Pelabuhan Semarang Pada Masa Kolonial Belanda Abad XX." In Arung Samudera: Persembahan Memperingati Sembilan Windu A.B. Lapian, edited by Edi Sedyawati and Susanto Zuhdi, 21-40. Depok: Lembaga Penelitian Universitas Indonesia - Yayasan Adikarya IKAPI.

Susilowati, Endang. 2004. "Pasang Surut Pelabuhan Rakyat di Pelabuhan Banjarmasin, 1880-1990." $\mathrm{PhD}$ Dissertation, Universitas Indonesia.

Touwen, Jeroen. 2001. Extremes in The Archipelago: Trade and Economic Development in the Outer Islands of Indonesia 1900-1941. Leiden: KITLV Press.

Zuhdi, Susanto. 1994. "Fungsi Militer Pelabuhan dan Kota Cilacap (1830-1942)." Jurnal Sejarah 5: 76-89.

Zuhdi, S. 2010. Sejarah Buton Yang Terabaikan: Labu Rope Labu Wana. Jakarta: Rajawali Press. 